\title{
FENOMENA MEROKOK PADA ANAK USIA REMAJA: STUDI KUALITATIF
}

\author{
Yunus Elon ${ }^{1 *}$, Evelin Malinti ${ }^{2}$ \\ Fakultas Ilmu Keperawatan, Universitas Advent Indonesia \\ *email: yunus.elon@unai.edu
}

\begin{abstract}
Abstrak
Merokok dikalangan remaja merupakan salah satu fenomena yang cukup memprihatinkan. Peringatan bahaya merokok yang terdapat pada bungkus rokok tidak memberikan pengaruh yang signifikan dalam mengurangi jumlah perokok dan bahkan sebaliknya jumlah perokok terus meningkat. Tujuan yang hendak dicapai dalam penelitian ini adalah: untuk mendeskripsikan gambaran merokok pada anak usia remaja. Metode yang digunakan pada penelitian ini adalah metode kualitatif dengan tehnik accidental sampling. Informan yang digunakan dalam penelitian ini berjumlah 10 orang pelajar SMP yang berdomisili di kecamatan Parongpong. Hasil penelitian menunjukkan fenomena merokok pada anak usia remaja antar lain: alasan remaja merokok; coba-coba, sahabat, orang tua, iseng-iseng dan ketagihan. Hal-hal yang dirasakan saat pertama kali merokok antara lain; pahit, batuk, ketagihan/kecanduan, kebiasaan, keterusan, pusing, tidak enak, nyesel dan tenggorokan kering. Pandangan informan tentang seseorang yang merokok antara lain: macho/keren, gaul, percaya diri, dan jelek. Respon orang tua, guru dan teman saat informan merokok yaitu: marah, melarang, dihukum, ngajakin. Waktu yang biasa digunakan oleh informan untuk merokok: saat berkumpul bersama teman, sehabis makan dan cuaca dingin. Tanggapan tentang merokok saat ini; dinikmati dan enak. Hasil penelitian ini diharapkan dapat menjadikan referensi untuk melakukan penelitian tentang status merokok dalam hubungan dengan kualitas hidup di kalangan remaja.
\end{abstract}

Kata kunci: Fenomena, Merokok; Remaja;

\section{Abstract}

Smoking among teenagers is one phenomenon that is quite alarming. The warning of the dangers of smoking contained in cigarette packs does not have a significant influence in reducing the number of smokers and on the contrary the number of smokers continues to increase. The objectives to be achieved in this study are: to describe the picture of smoking in adolescents. The method used in this study is a qualitative method with accidental sampling technique. The informants used in this study were 10 junior high school students domiciled in Parongpong sub-district. The results of the study showed the phenomenon of smoking in adolescent were: teenager's reasons of smoking; trial and error, friends, parents, fad and addiction. Things that are felt when first smoking include; bitter, coughing, addicted, habits, continuity, dizziness, discomfort, pain and dry throat. The informant's view of someone who smokes includes: macho / cool, slang, confident, and worse. The response of parents, teachers and friends when informants smoking were: angry, banned, punished, ask. The time commonly used by informants to smoke: when gathering with friends, after meals and cold weather. Feedback about smoking: enjoyed and delicious. The results of this study can be a reference to do research on smoking status in relation to quality of life among adolescents

Keywords: Adolescents, Fenomenon, Smoking

\section{Pendahuluan}

Rokok termasuk dalam golongan zat adiktif yang dapat mengakibatkan adiksi atau ketagihan serta dependensi atau ketergantungan bagi orang yang menghisapnya. Merokok menjadi salah satu fenomena sosial yang unik dikalangan masyarakat saat ini. Akibat buruk dari merokok yang dapat mengancam kesehatan, bahkan kematian telah diketahui masyarakat pada umumnya namun tetap saja rokok mendapat perhatian terutama dari kalangan perokok itu sendiri. Fenomena semacam ini tentu merupakan salah satu bentuk pergeseran dimana rokok dalam kehidupan manusia yang pada awalnya hanya merupakan 
kebutuhan sekunder sekarang berubah menjadi kebutuhan primer (Faishal, 2011).

Menurut Subuh (2016), saat ini Indonesia berada pada tahap memprihatinkan dalam hal konsumsi tembakau, terutama rokok. Menurut data kementrian kesehatan terjadi peningkatan prevalensi perokok dari $27 \%$ pada tahun 1995 , meningkat menjadi 36.3 $\%$ tahun 2013 dengan kata lain 20 tahun lalu setiap 3 orang Indonesia 1 diantaranya perokok. Sekarang ini di Indonesia, dari setiap 3 orang, 2 diantaranya merokok (Kemenkes RI, 2016).

Data Riskesdas (2018) menunjukkan bahwa terjadi peningkatan jumlah perokok generasi muda. Perokok usia 10-18 tahun mencapai $9.1 \%$. atau naik $0,3 \%$ dari tahun 2016. Ini adalah sebuah fenomena yang cukup mengkuatirkan, mengingat generasi muda adalah generasi penerus bangsa.

Penyebab perilaku merokok pada anak usia sekolah diantaranya adalah rasa ingin tahu, pengaruh iklan rokok, dan lingkungan keluarga (Huda, 2018). Lingkunagn sosial seperti teman sebaya, guru, idola, dan lingkungan budaya memiliki hubungan yang signifikan dengan perilaku merokok pada remaja (Sutha, 2016). Perokok usia remaja kebanyakan bejenis kelamin laki-laki, pencapaian akademik yang buruk, memiliki orang tua perokok dan merasa kesepian. Sedangkan kejadian merokok pada remaja yang taat beragama didapati angka yang rendah (Lim, et al., 2017).

Penelitian yang dilakukan oleh Prabandari dan Dewi (2016) menunjukkan bahwa faktor yang mendorong remaja Indonesia memulai merokok adalah iklan rokok, orang terdekat seperti keluarga atau teman yang merokok. Perokok yang telah memulai kebiasaan merokok diawal masa remaja cenderung mengalami ketergantungan terhadap rokok (Rukmi, 2019).

Berdasarkan pengamatan peneliti, perokok remaja awal sering ditemui merokok bahkan ditempat umum. Anak-anak remaja yang masih sekolah ditahap SMP, bahkan tidak segan merokok saat masih menggunkan seragam sekolah. Hal inilah yang melatarbelakangi keinginan peneliti untuk memperoleh data tentang alasan dan perasaan perokok remaja ini tentang merokok.

\section{Bahan dan Metode Penelitian}

Penelitian ini menggunakan metode kualitatif atau naturalistik karena dilakukan pada kondisi yang alamiah. Sugiyono (2013) mengemukakan bahwa metode penelitian kualitatif adalah metode penelitian yang digunakan untuk meneliti pada kondisi obyek yang alamiah, dimana peneliti adalah sebagai instrumen kunci, teknik pengumpulan data dilakukan secara triangulasi (gabungan) data yang di peroleh narasumber satu dengan yang lain dan data yang akurat dengan cara mengunakan observasi partisipasi, wawancara mendalam, dan mengumpulkan data yang bersifat dokumentasi untuk sumber data yang sama secara bersamaan dan serentak.

Populasi dalam penelitian ini adalah remaja SMP yang ada di RW 03 Desa Cihanjuang Rahayu Kecamatan Parongpong. Sampel yang digunakan sebagai informan dalam penelitian ini adalah 10 orang remaja laki-laki yang dipilih menggunakan metode accidental sampling. Setelah Informed consent ditanda tangani orang tua, peneliti melakukan proses wawancara.

Proses analisis data dalam penelitian ini menggunakan interpretasi metodologi dari (Sugiyono, 2011), adapun langkah-langkahnya sebagai berikut:

1. Mengumpulkan deskripsi fenomena berdasarkan informasi yang disampaikan narasumber. Setelah melakukan wawancara mendalam dengan narasumber, Investigator melakukan transkripsi dari hasil wawancara yang didapatkan.

2. Membaca seluruh deskripsi fenomena berdasarkan informasi yang disampaikan narasumber. Investigator membaca kembali hasil transkripsi untuk mendapatkan kata kunci dari Narasumber.

3. Membaca kembali transkrip, selanjutnya mengutip pernyataan yang signifikan. Investigator membaca secara berulangulang untuk mendapatkan kata kunci sesuai dengan tujuan penelitian. Pada tahap ini, Investigator menggunakan etik dan emik.

4. Mencoba untuk menguraikan makna dari setiap pernyataan yang signifikan. Investigator menentukan kategori dari etik dan emik yang ditentukan.

5. Kembali ke subjek untuk validasi dari deskripsi. Investigator kembali kepada Narasumber untuk melakukan validasi. 
Validasi yang dilakukan Investigator menggunakan wawancara melalui telfon.

6. Jika tedapat data baru yang terungkap selama validasi, Investigator masukkan ke dalam sebuah deskripsi lengkap. Jika Investigator menemukan deskripsi baru, maka akan dimasukan ke dalam deskripsi lengkap.

\section{Hasil dan Pembahasan}

1. Data informan penelitian

Dalam melakukan wawancara, peneliti menggunakan panduan wawancara terstruktur. Adapun waktu yang dibutuhkan untuk wawancara 6-10 menit. Peneliti melakukan minimal 2 kali wawancara (1 kali wawancara dan 1 kali konfirmasi) dalam melakukan wawancara. Ada 10 informan siswa SMP yang berdomisisli di RW 3 Cihanjuang Rahayu. Berikut adalah data informan dalam tabel 1 dibawah ini:

Tabel 1. Deskripsi Data Informan

\begin{tabular}{|c|c|c|c|}
\hline No & Inisial & Umur & Mulai Merokok \\
\hline 1 & $\mathrm{D}$ & 15 & "Dari kelas...1 SMP." \\
\hline 2 & $\mathrm{~T}$ & 15 & "Dari kelas 1 SMP Bang." \\
\hline 3 & A & 13 & "Kelas 1 SMP.” \\
\hline 4 & $\mathrm{D}$ & 14 & $\begin{array}{l}\text { "Dari kelas eeeh...kelas } 1 \\
\text { SMP bang." }\end{array}$ \\
\hline 5 & $\mathrm{CA}$ & 14 & $\begin{array}{l}\text { "Kelas enam SD bang.. } \\
\text { iyaa." }\end{array}$ \\
\hline 6 & W P & 14 & $\begin{array}{l}\text { "pas coba-coba kelas } 1 \\
\text { SMP." }\end{array}$ \\
\hline 7 & D R & 14 & "Sejak SD kelas 6." \\
\hline 8 & $\mathrm{R}$ & 16 & $\begin{array}{l}\text { "Awal semester satu kelas } \\
\text { Sembilan." }\end{array}$ \\
\hline 9 & A & 16 & "Sejak kelas satu SMP.” \\
\hline 10 & A G & 15 & "Sejak kelas dua SMP." \\
\hline
\end{tabular}

Sumber: Data Primer

Gambar 1. Rata-Rata Usia Informan

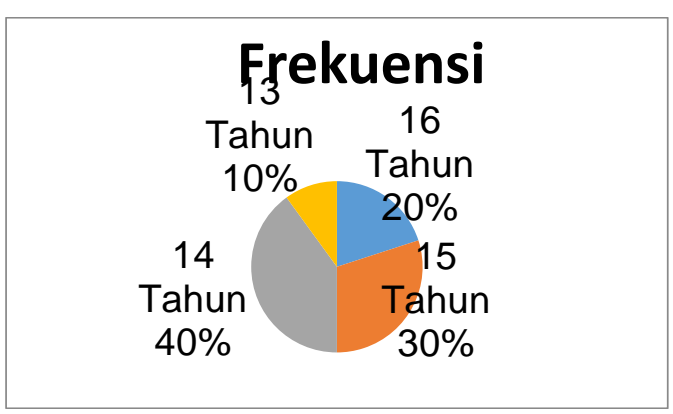

Sumber: Data Primer
Gambar 2. Informan Merokok

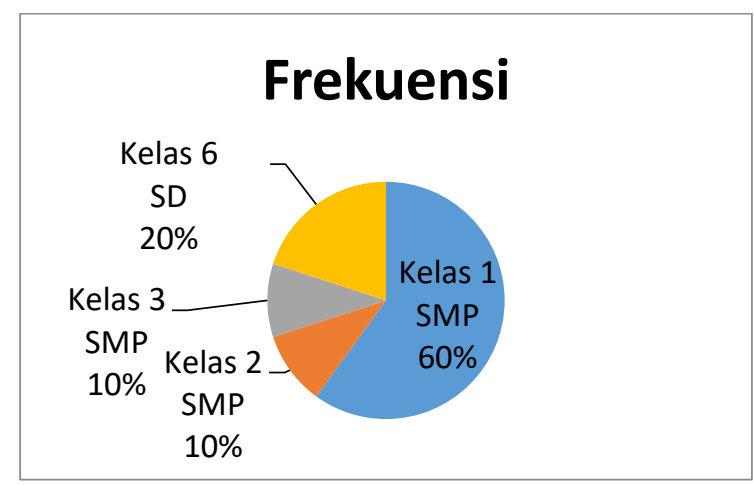

Sumber : Data Primer

Gambar 1 dan 2 memperlihatkan gambaran usia dan kelas informan mulai merokok. Frekuensi informan mulai merokok saat berusia 14 tahun sebesar 40\%, 15 tahun $30 \%, 16$ tahun $20 \%$ serta 13 tahun $10 \%$. Sementara $60 \%$ informan mulai merokok saat kelas 1 SMP, $20 \%$ saat kelas 6 SD dan $10 \%$ saat kelas 2 dan 3 SMP. Hal ini memperlihatkan bahwa remaja paling banyak mulai merokok saat kelas 1 SMP dan pada saat berusia 14 tahun.

Hurlock, (2007) mengatakan bahwa perilaku merokok seringkali dimulai di sekolah menengah pertama (SMP), bahkan sebelumnya. Pada saat seorang anak duduk di bangku sekolah menengah atas, merokok seringkali menjadi bagian dari kegiatankegiatan social yang dilakukan oleh si anak, diantara mereka tak jarang ada yang melakukannya di area-area terlarang, seperti di halaman sekolah, dikantin, di toilet, bahkan ada yang melakukannya di dalam kelas ketika jam istirahat. Remaja merasa harus banyakbanyak melakukan penyusaian diri jika tidak lagi dianggap sebagai anak kecil.

Sejalan dengan pendapat tersebut, Fagan (2008) menyatakan bahwa masa remaja merupakan masa yang rentan pada krisis aspek psikososial. Krisis aspek psikososial pada remaja merupakan krisis identitas yang berbentrokan dengan kebingungan. Krisis aspek psikososial ini terjadi karena remaja sedang berada dalam upaya mencari jati diri yang dibarengi ketidaksesuaian antara perkembangan psikis dan sosial. Untuk mengatasi tekanan yang diakibatkan krisis tersebut, remaja melakukan perilaku merokok sebagai cara mengatasi atau hanya sekedar mencoba-coba sesuatu yang baru dalam rangka menemukan jati dirinya. Perilaku merokok 
merupakan perilaku yang dapat dilakukan remaja dalam upaya meneguhkan identitas dirinya.

Di samping itu, Karyadi (2008) mengatakan masa remaja merupakan masa peralihan yang mana remaja menjadi labil dan mudah terpengaruh. Dalam konteks ini, labil dan mudah terpengaruh terkait dengan perilaku remaja yang mudah berubah dan kerentanan remaja untuk dipengaruhi oleh lingkungan sekitarnya. Dalam kondisi yang belum pasti inilah remaja rentan mengalami permasalahan dan perperilaku negatif karena masih labil dan emosinya belum terbentuk secara matang, salah satunya adalah merokok.

2. Hal yang menjadi alasan informan merokok

Berdasarkan wawancara yang dilakukan terhadap ke 10 informan didapati bahwa tujuh

(7) orang merokok karena "Sahabat", enam

(6) orang mengatakan alasan "Coba-coba", "Iseng" dan "Ketagihan", serta satu (1) orang karena melihat "Orang tua".

Tabel 2 Alasan informan merokok

\begin{tabular}{|c|c|}
\hline Emik & Kategorik \\
\hline $\begin{array}{l}\text { I 1: "Liat temen merokok, jadi } \\
\text { pengen coba-coba, lama } \\
\text { kelamaan jadi ketagihan." } \\
\text { I 2: "Yah.. orang tua merokok } \\
\text { jadi pengen.. Main sama temen } \\
\text { diajakin ngerokok jadi pengen } \\
\text { coba-coba." } \\
\text { I 3: "Awalnya pengen coba- } \\
\text { coba ehh ternyata jadi } \\
\text { ketagihan." "Awal mulanya } \\
\text { I 4: } \\
\text { yaa...kebawa sama temen, } \\
\text { coba-coba..coba-coba satu } \\
\text { bantang hoohhh satu batang } \\
\text { satu batang dan ketagihan } \\
\text { bang." "Diajakin temen bang.. } \\
\text { I 5: "Data) } \\
\text { di..ke..ya..(terbata-bata) } \\
\text { diketerusannya jadi pengen lagi } \\
\text { bang jadi ketagihan..udah itu } \\
\text { aja bang." } \\
\text { I 6: "Awalnya sih coba2 sih, } \\
\text { pertama juga pas rasain batuk, } \\
\text { eeh lama-kelamaan kecanduan" } \\
\text { I 7: "Ya iseng-iseng sih } \\
\text { pertamanya mah, lihat teman- } \\
\text { teman merokok, kepengen }\end{array}$ & $\begin{array}{l}\text { Kognator: } \\
\text { - Coba-coba } \\
\text { - Sahabat } \\
\text { - Orang tua } \\
\text { - Iseng } \\
\text { - ketagihan }\end{array}$ \\
\hline
\end{tabular}

nyobain-nyobain jadi

ketagihan."

I 8: "Awalnya kebawa sama

teman, dirasa-rasa enak rokok

teh, jadi kebiasaan sampai

disini sampai sekarang."

I 9: "Tegang sih, tapi rasa saya

gugup tapi rasa pengen terus

coba-coba aja."

I 10: "ngikut-ngikut teman dan

orang tua merokok"

Sumber: data primer

Berdasarkan tabel 2 diatas didapati bahwa alasan informan merokok dikarenakan ingin coba-coba, Pengaruh sahabat, isengiseng, ketagihan serta melihat orang tua menjadi alasan remaja merokok.

Hal ini didukung oleh Leavy (dalam Nasution, 2007) ada dua faktor yang dapat memotivasi dan membuat remaja memilih untuk merokok, yaitu faktor internal dan eksternal. Salah satu faktor internal yang dapat memotivasi dan membuat remaja memilih untuk merokok adalah faktor kepribadian. Pada faktor kepribadian individu mencoba merokok karena alasan ingin tahu. Hasil penelitian yang ditemukan oleh Wulan (2012) menyimpulkan bahwa rasa ingin tahu yang besar pada remaja merupakan faktor yang paling dominan yang mendorong remaja untuk merokok.

Faktor internal yang lain adalah faktor biologis yaitu kandungan nikotin pada rokok. Nikotin dalam rokok merupakan salah satu bahan kimia yang berperan penting pada ketergantungan merokok (Leavy dalam Nasution, 2007). Nikotin membuat si perokok merasa relaks dan kemudian merasa lebih bersemangat yang dikenal sebagai phase effect. Hal inilah yang membuat perokok menjadi kecanduan untuk merokok (Sukmasari, 2016).

Faktor eksternal yang dapat memotivasi dan membuat remaja memilih untuk merokok adalah pengaruh orang tua dan pengaruh teman (Rukmi, 2019). Hasil penelitian Widiansyah (2014) menemukan bahwa orang tua merupakan orang yang berpengaruh timbulnya perilaku merokok dari lingkungan keluarga. Remaja yang melihat orang tua mereka merokok akan menimbulkan rasa pada diri mereka untuk mencoba apa yang dilakukan orang tua mereka, yaitu perilaku 
merokok. Hasil penelitian yang dikemukakan oleh Sari (2016) bahwa terdapat hubungan yang signifikan antara pengaruh teman dengan perilaku merokok pada remaja. Semakin kuat pengaruh teman, maka semakin besar remaja laki-laki menjadi perilaku merokok aktif.

3. Hal yang dirasakan informan ketika pertama kali merokok

Hasil wawancara memperlihatkan gambaran tentang hal yang dirasakan oleh informan ketika pertama kali merokok yaitu, pahit, batuk, ketagihan/kecanduan, kebiasaan, keterusan, pusing, tidak enak, nyesel dan tenggorokan kering.

Tabel 3 Hal yang dirasakan informan ketika pertama kali merokok

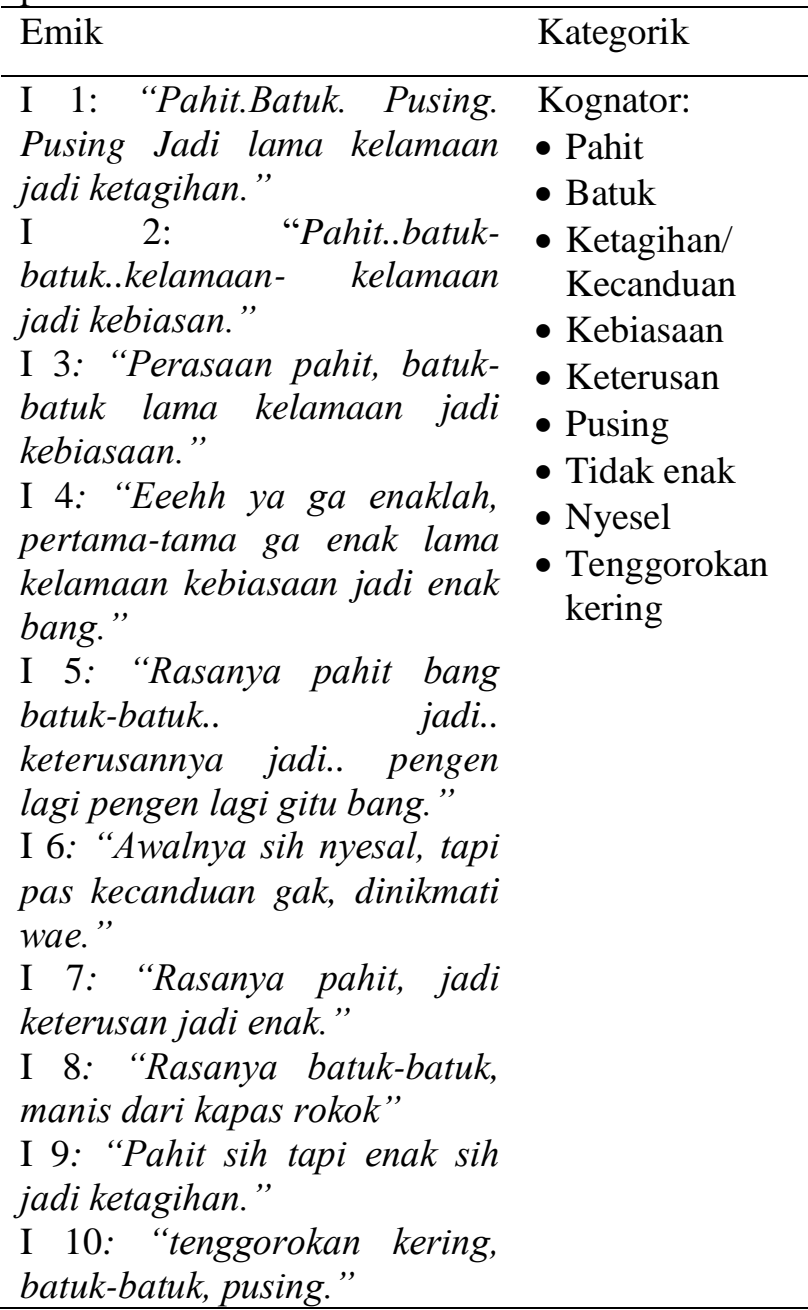

Sumber: Data primer

Tabel 3 memperlihatkan respon informan saat pertama kali merokok adalah; "Pahit" tujuh (7) orang, "batuk" enam (6) orang, "ketagihan/kebiasaan/ keterusan/kecanduan enam" (6) orang dan yang terakhir mengatakan " pusing" dua (2) orang. Seorang yang pertama kali merokok mengalami gejala-gejala seperti batuk-batuk, perut mual, dan lidahnya terasa pahit. Namun, sebagian pemula yang mengabaikan gejalagejala tersebut, berlanjut menjadi kebiasaan dan akhirnya menjadi ketagihan. Kebiasaan yang dimaksud yaitu selalu merokok sesudah makan dan menikmati rokok sambil minum kopi sedangkan ketagihan yaitu adanya rasa ingin merokok yang menggebu, tidak bisa hidup selama setengah hari tanpa rokok,merasa tidak tahan bila kehabisan rokok dan sebagian kenikmatan rokok terjadi saat menyalakan rokok (Yusnia, 2015).

Rasa pusing yang dirasakan pada saat pertama kali merokok merupakan akibat dari merasakan nikotin untuk pertama kalinya yang berdampak pada pengendapan berlebihan di dalam reseptor nikotin yang tinggal lebih lama (Ongano,2016). Asap rokok mengandung karbonmonoksida, yang terikat ke dalam hemoglobin yang bersirkulasi di dalam SDM (Sel Darah Merah), yang memiliki kecenderungan lebih tinggi untuk terikat dengan hemoglobin dibandingkan oksigen. Pada saat hemoglobin berikatan dengan karbonmonoksida karbonmonoksida tidak gampang terlepas. Hal itu mengakibatkan penurunan oksigen dalam darah. Penurunan oksigen (hipoksia) dapat berujung pada rasa pusing, pingsan dan rasa lelah (Ananditya, 2015).

(2015) merokok dapat menyebabkan kecanduan nikotin. Zat nikotin dapat menganggu perhatian, konsentrasi dan kemampuan kognitif, karena nikotin dapat meningkatkan finger-tapping rate yaitu respon motorik dalam tes fokus perhatian. Tetapi hal ini akan berkurang bila mereka diberi nikotin dan remaja yang merokok juga akan berpengaruh kepada nilai atau prestasi yang ia dapat karena mereka cenderung kurang memahami pelajaran dan kebiasaan menghisap tembakau akan berpengaruh terhadap kesehatan fungsi otak dan psikis.

\section{Pandangan tentang merokok}

Berdasarkan hasil wawancara didapatkan, bahwa informan memiliki pandangan tentang merokok yaitu; Macho/keren, gaul, percaya diri. Jelek dan terlihat keren. Tabel 4 menunjukkan emik dan kategorik dari 
pandangan informan tentang seorang yang merokok.

Tabel 4 Pandangan Informan tentang seseorang yang merokok

\begin{tabular}{|c|c|}
\hline Emik & Kategorik \\
\hline $\begin{array}{l}\text { I 1: "Liat orang tua seperti } \\
\text { lebih maco, lebih seram, lebih } \\
\text { dewasa." } \\
\text { I 2: "Maco..keren." } \\
\text { I 3: "Pandangan merokok itu } \\
\text { seperti lebih maco dan keren." } \\
\text { I 4: "Pandangan nya } \\
\text { sih..memang jelek bang anak } \\
\text { esempe merokok tapi kan udah } \\
\text { kebiasaan jadi susah.." } \\
\text { I 5: "Jadi gaul ya bang..keren } \\
\text { gitu diliat orang jadi } \\
\text { keren..udah itu aja yang..iya." } \\
\text { I 6: "Yah pandangan merokok } \\
\text { gimana ya, dulu pas lihat } \\
\text { teman aja jadi ikut-ikutan"” } \\
\text { I 7: "Pandanngan saya ya } \\
\text { tentang kalau buat sama saya } \\
\text { mah kesukaan kalau merokok", } \\
\text { I 8: "Pandangan saya menjadi } \\
\text { lebih macho dan keren"” } \\
\text { I 9: "Lebih macho } \\
\text { keliatannya." } \\
\text { I 10: "percaya diri, terus } \\
\text { seperti lebih maco." }\end{array}$ & $\begin{array}{l}\text { Kognator: } \\
\text { - Macho/keren } \\
\text { - Gaul } \\
\text { - Percaya diri } \\
\text { - Jelek } \\
\text { - Terlihat } \\
\text { dewasa }\end{array}$ \\
\hline
\end{tabular}

Sumber: data primer

Pada tabel 4 pandangan tentang merokok yang mengatakan "Macho/keren" tujuh (7) orang, "Jelek" satu (1) orang, "Percaya Diri" satu (1) orang, "lebih Dewasa" satu (1) orang. Ogden (2010) mengatakan bahwa merokok biasanya dimulai sebelum usia 19 tahun dan individu yang mulai merokok pada usia dewasa jumlahnya sangat kecil. Faktor kognitif berperan besar ketika individu mulai merokok, antara lain: menghubungkan perilaku merokok dengan keren, kesenangan, kebahagiaan, keberanian, kesetia-kawanan dan percaya diri. Faktor lainnya adalah memiliki orang-tua perokok, tekanan teman sebaya untuk merokok, menjadi pemimpin dalam kegiatan sosial dan tidak adanya kebijakan sekolah terhadap perilaku merokok. Chezhian et al. (2015), mendapatkan bahwa hal yang dirasakan perokok saat meroko adalah perasaan senang.
5. Bagaimana tanggapan atau respon lingkungan (orang tua, guru, teman) yang anda raasakan pada saat anda merokok?

Hasil wawancara terhadap informan, memperlihatkan tanggapan orang tua, guru dan teman terhadap perokok; Marah, melarang, dihukum, dan agajakin.

Tabel 5 Respon orang tua, guru dan teman saat informan merokok

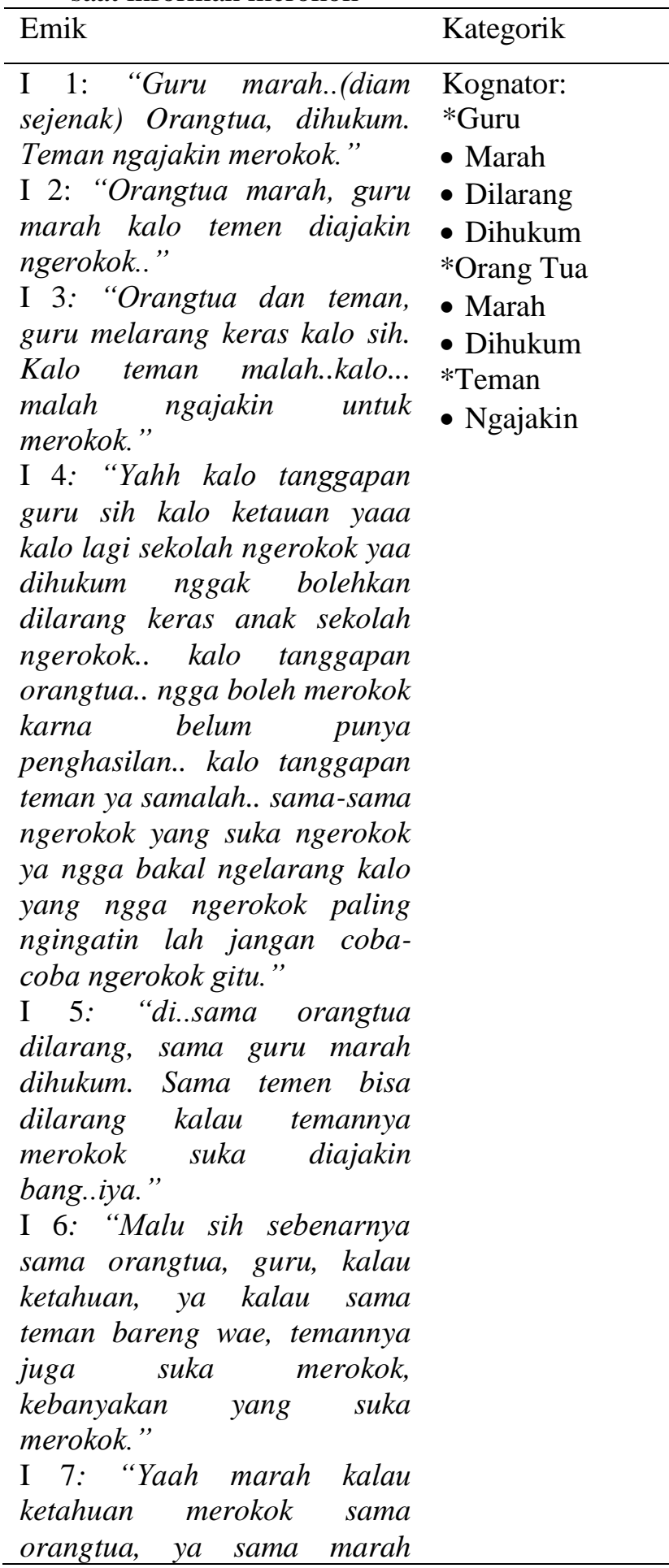


kalau ketahuaan sama guru di

hukum, kalau teman-teman sama aja merokok, gimana temannya merokok bareng biasa aja ikut merokok."

I 8: "Orangtua pertama kali marah, dah lama-kelamahan dah ngebolehin juga."

I 9: "Kalau orangtua sih dah jelas melarang, kalau teman sih mendukung karena merekakan juga ikut merokok, kalau guru mah dah jelas melarang."

I 10: "orang tua dulu belum tahu, aku belum merokok, kalau teman malah mengajak saya merokok bareng."

Sumber: data primer

Tabel 5 memberikan gambaran tentang respon orang tua, guru dan teman saat mengetahui informan merokok yaitu; "Marah" lima (5) orang, "Dilarang" tiga (3) orang "Dihukum" dua (2) orang, dan "diajakain teman" lima (5) orang. Respon orang-orang disekeliling perokok remaja mempengaruhi keingginan merokok pada remaja. Jika anakanak melihat orang tua, saudara kandung, guru, idola, atau teman dekat merokok hal ini mendorong mereka melakukan hal yang sama (McGee, et al., 2015).

Remaja perlu mengerti bahaya merokok. Orang tua harus menggunakan teknik komunikasi yang baik untuk menetapkan peraturan atau larangan merokok. Memarahi atau membuat remaja takut akan hukuman merupakan tindakan kurang tepat. Memberi pengertian, menghargai pendapat remaja, dan memberikan pujian bila melakukan hal yang positif, dan membangkitkan percaya diri akan membantu remaja mengalahkan tekanan atau ajakan dari teman yang merokok (Ben-Joseph, 2016).

Orang tua yang membuat aturan larangan merokok dirumah, sikap menolak lingkungan sosial terhadap perilaku merokok remaja akan menolong mengurangi tingkat merokok pada remaja. Anak remaja menghargai orang tua yang memberi perhatian khusus dengan melarang merokok (BMC Public Health, 2009). Peraturan disekolah untuk tidak merokok yang harus diikuti oleh siswa maupun guru dapat membantu menekan keinginan merokok pada remaja (Roohafza, et al., 2014). Remaja perlu menghindari temanteman yang memiliki kebiasaan merokok dan melibatkan diri dalam aktifitas fisik seperti olahraga (Ben-Joseph, 2016).

6. Kapan biasanya anda merokok, dan bagaimana Tanggapan Terhadap Kebiasaan Merokok Saat Ini?

Hasil wawancara memperlihatkan tentang waktu yang biasa digunakan oleh informan untuk merokok yaitu; Saat berkumpul dengan teman, sehabis makan, cuaca dingin dan tanggapan terhadap kebiasaan merokok saat ini yaitu; dinikmati, enak dan tenang.

Tabel 6 waktu yang biasa digunakan untuk merokok dan tanggapan merokok saat ini.

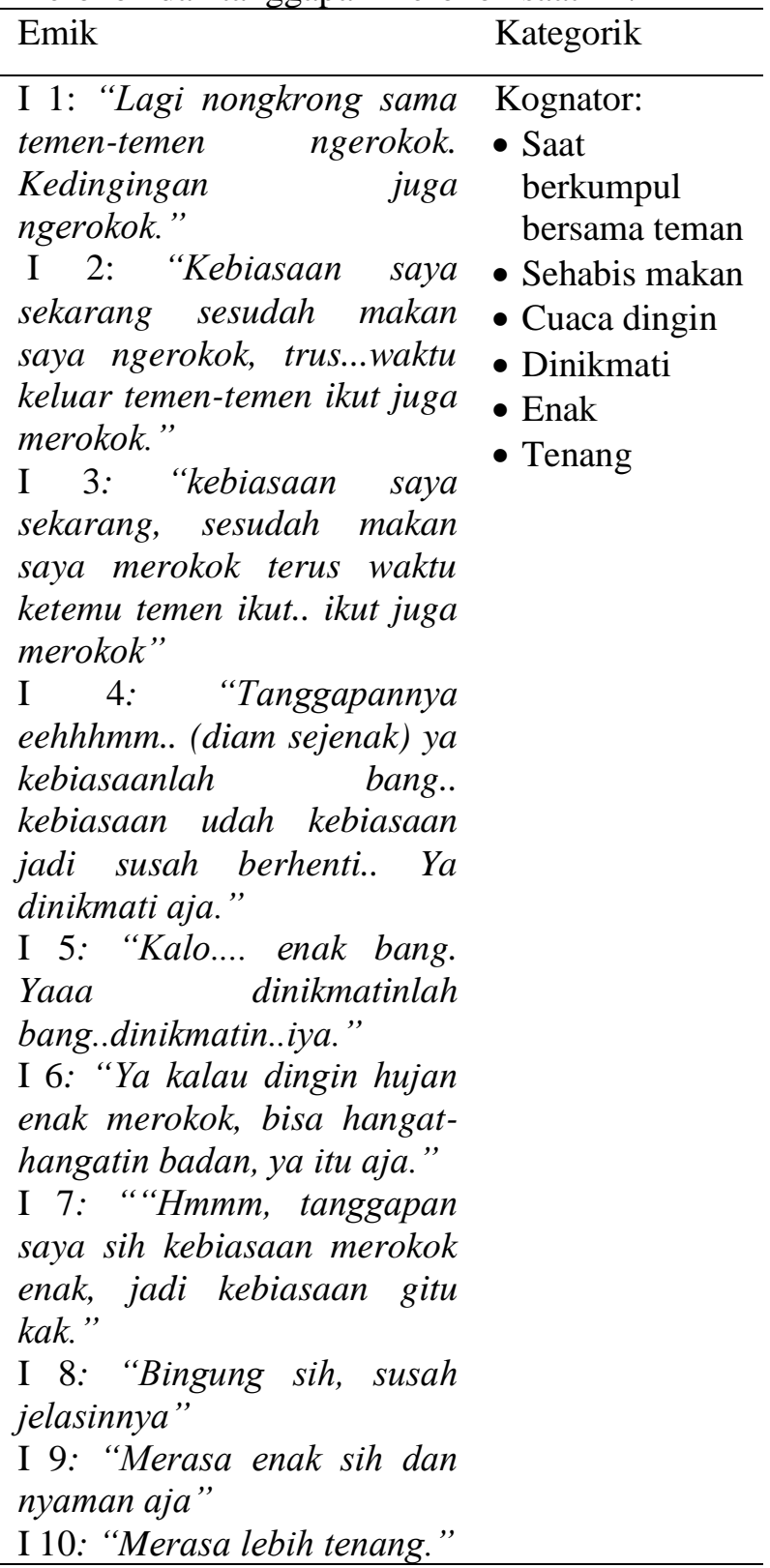


Sumber; data primer

Pada tabel 6 ditunjukkan gambaran tentang waktu yang biasa digunakan oleh informan untuk merokok antara lain; "lagi kumpul dengan teman" tiga (3) orang, "sesudah makan" dua (2) orang, "cuaca dingin" dua (2) orang. Serta tanggapan tentang kebiasaan merokok saat ini yaitu; "dinikmati" lima (5) orang, "enak" tiga (3) orang dan "Tenang" satu (1) orang . Menurut Wismanto dan Sarwo (2007) ada 4 tipe perilaku merokok, keempat tipe tersebut adalah : 1. Tipe perokok yang dipengaruhi oleh perasaan positif. Dengan merokok seseorang merasakan penambahan rasa yang positif. Dalam hal ini dibagi dalam 3 sub tipe:

a. Pleasure relaxation, perilaku merokok hanya untuk menambah atau meningkatkan kenikmatan yang sudah didapat, misalnya merokok setelah minum kopi atau makan.

b. Stimulation to pick them up, perilaku merokok hanya dilakukan sekedarnya untuk menyenangkan perasaan.

c. Pleasure of handling the cigarette, kenikmatan yang diperoleh dengan memegang rokok. Sangat spesifik pada perokok pipa. Perokok pipa akan menghabiskan waktu untuk mengisi pipa dengan tembakau sedangkan untuk menghisapnya hanya dibutuhkan waktu beberapa menit saja atau perokok lebih senang berlama-lama memainkan rokoknya dengan jari-jarinya lama

sebelum dia menyalakan dengan api. 2) Perilaku merokok yang dipengaruhi oleh perasaan negatif. Banyak orang menggunakan rokok untuk mengurangi perasaan negatif, misalnya bila marah, cemas ataupun gelisah, rokok dianggap sebagai penyelamat. 3) Perilaku merokok yang adiktif (psychological addiction). Bagi yang sudah adiksi, akan menambah dosis rokok yang digunakan setiap saat setelah efek dari rokok yang dihisapnya berkurang. Mereka umumnya akan pergi keluar rumah membeli rokok, walau tengah malam sekalipun. 4) Perilaku merokok yang sudah menjadi kebiasaan. Mereka menggunakan rokok sama sekali bukan karena untuk mengendalikan perasaan mereka, tetapi karena benar-benar sudah kebiasaan rutin. Pada tipe orang seperti ini merokok merupakan suatu perilaku yang bersifat otomatis. Dan berdasarkan pandangan Laventhal \& Cleary (dalam Komasari \&
Fadilla 2007) mengatakan bahwa remaja merokok lebih merupakan upaya-upaya untuk dapat diterima di lingkungan. Hampir 28\% subjek menyatakan bahwa konsumsi terbesar rokok ketika mereka sedang berkumpul dengan teman-temannya yaitu apakah mereka nongkrong di mall, begadang, santai, kumpulkumpul saja, yang mengatakan habis makan $13 \%$ dan dinikmati sendiri $2 \%$.

\section{Kesimpulan}

1. Usia informan yang merokok terbanyak pada usia 14 tahun dan duduk dikelas 1 smp. Hal ini sejalan dengan data RISKESDAS tahun 2018 yakni usia peokok 10-18 tahun mengalami peningkatan setiap tahun.

2. Hal yang menajdi alasan informan merokok yaitu; Sahabat, Coba-coba, Iseng, Ketagihan, serta karena melihat Oang tua.

3. Hal-hal yang dirasakan oleh informan ketika pertama kali merokok yaitu, pahit, batuk, ketagihan/kecanduan, kebiasaan, keterusan, pusing, tidak enak, nyesel dan tenggorokan kering.

4. Pandangan informan tentang merokok yaitu; Macho/keren, gaul, percaya diri. Jelek dan terlihat keren serta terlihat dewasa.

5. Tanggapan atau respon lingkungan (orang tua, guru, teman) yang anda raasakan pada saat anda merokok yaitu; Marah, melarang, dihukum, dan agajakin.

6. Waktu yang biasa digunakan untuk merokok serta yaitu; Saat berkumpul dengan teman, sehabis makan, cuaca dingin dan tanggapan terhadap kebiasaan merokok saat ini yaitu; dinikmati, enak dan tenang.

\section{Daftar Pustaka}

Ananditya, T. (2017). Kenapa saat Saya Merokok Kepala ini selalu Pusing? http://www.alodokter.com/komunitas/to pic/kenapa-saat-saya- merokok-kepalaini-selalu-pusing

Arwani Faishal, (2011). Merokok dalam perspektif hukum islam. http://ilmukitaimam.blogspot.co.id/2012/04/merokok- 
dalam-perspektif-hukum-islam_24.html (05 mei 2017)

Ben-Joseph, E. P. (2016). Kids and smoking. Kids Helath. Available at: https://kidshealth.org/en/parents/smokin g.html

Chezhian, C., Murthy, S., Prasad, S., Kasav, J. B., Mohan, S. K., Sharma, S., ... et al. (2015). Exploring factors that influence smoking initiation ad cesation among current smokers. Journal of Clinical \& Diagnostic Research. 9(5). doi: 10.7860/JCDR/2015/12047.5917

Fagan. (2008). Psikologi Remaja. PT Gramedia. Jakarta.

Huda, A. K. (2018). Gambaran penyebab perilaku merokok pada anak usia sekolah. Naskah Publikasi. Available at: eprints.ums.ac.id/59869/29/ Naskah\%20Publikasi-4.pdf

Hurlock B.E, (2007). Perkembangan Anak. Jilid 1. Penerbit Erlangga. Jakarta.

Ismanto, Kaluas, Inggrith., , A. Y., \& Kundre, R.M. (2015). Perbedaan Terapi Bermain Puzzle dan Bercerita Terhadap Kecemasan Anak Usia Prasekolah (3-5 Tahun) Selama Hospitalisasi di Ruang Anak RS TK. III. R. W. Mongisidi Manado. eJournal Keperawatan (e-Kp) Volume 3 Nomer 2. (05 mei 2017).

Karyadi (2008) Hubungan pola asuh keluarga terhadap perilaku merokok pada remaja pria di Desa Kenteng Kecamatan Nogosari Kabupaten Boyolali. Skripsi (tidak diterbitkan) Surakarta: Universitas Muhammadiyah Surakarta (06 mei 2017).

Kementrian kesehatan repulik Indonesia (2016). HTTS 2016: Suarakan kebenaran, jangan bunuh dirimu dengan candu rokok.

shttp://www.depkes.go.id/article/print/1 6060300002/htts-2016-suarakankebenaran-jangan-bunuh-dirimudengan-candu-rokok.html

Leventhal, G.S., Karuza, J., \& Fry, W.R (1988). Beyond fairness: A theory of allocation preferences. In G. Mikula (ed.), Justice and social interaction; 167-218. (05 mei 2017).

Lim, K. H., Lim, H. L., Teh, C. H., Kee, C.C., Khoo, Y. Y., ganapaty, S. S., Ling, M. Y. J., ... et al. (2017). Smoking among school-going adolescents in selected secondary schools in Peninsular Malaysia- finsings from the Malaysian Adolescents health Risk Behaviour study. Tobacco Induced

Diseases201715:9

https://doi.org/10.1186/s12971-0160108-5

McGee, C. E., Trigwell, J., Fairclogh, S.J., Murphy, R. C., Porcellato, L., Ussher, M., \& Foweather, L. (2015). Influence of family and friend smoking on intentions to smoke and smoking-related attitudes and refusal self-efficacy among 9-10 year old children from deprived neighbourhoods: a cross-sectional study. BMC Public Health. 2015; 15: 225. doi: 10.1186/s12889-015-1513-z

Nasution, I. K. (2007). Stres pada Remaja. Universitas Sumatera Utara. Diunduh http://repository.usu.ac.id/bitstream/123 $456789 / 3637 / 11 / 132316815 \% 2$ 81\%29.pdf (25 Januari 2017)

Nasution, I. K. (2007). Perilaku Merokok pada Remaja. Program Studi Psikologi Fakultas Kedokteran Universitas Sumatra Utara: Medan.

Ogden CL, Carroll MD, Curtin LR, Lamb MM, Flegal KM. (2010). Prevalence of High Body Mass Index in US Children and Adolescents, 2007-2008. Journal of the American Medical Association 303(3)

Onggano, N. (2015). Kenapa orang yang baru pertama kali merokok merasa pusing dan lelah? https://www.galena.co.id/q/kenapaorang-yang- baru-pertama-kalimerokok-merasa-pusing-dan-lelah (04 Mei 2017)

Pernyataan Menteri Kesehatan RI, yang disampaikan oleh Dirjen Pencegahan dan Pengendalian Penyakit (P2P) Kemenkes RI, dr. H. Mohamad Subuh, MPPM, pada acara talkshow sebagai rangkaian puncak peringatan Hari Tanpa Tembakau Sedunia (HTTS) tahun 2016 di Taman Ismail Marzuki, Jakarta (31/5).

Prabandari, Y. S., \& Dewi, A. (2016). How Indonesian youth perceive cigarette advertising? A cross-sectional study among Indonesian high school students. Glob Helath Action. 2016; 9: doi: 10.3402/gha.v9.30914

Roohafzah, H., Heidari, K., Omidi, R., Alina, 
T., Sadegghi, M., Mohammad-Shafiee, G., \& Naji, M. (2014). Adolescent Perception on School Environment and Smoking Behavior: Analysis of Isfahan Tobacco use Prevention Program. Int J Prev Med. 2014 Dec; 5(Suppl 2): S139S145.

Rukmi, S. (2019). Tobacco use and adolescents in Indonesia: Narrative review of determinants. KnE Life Sciences | The 3rd International Meeting of Public Health and the 1st Young Scholar Symposium on Public Health pages: $69-84$

Sari, D. (2016). Hubungan Antara Pengaruh Keluarga, Teman, Iklan Terhadap Perilaku Merokok pada Siswa di SMPN 6 Wonogiri. Universitas Muhammadiyah Surakarta: Skripsi

Sugiyono. (2011). Metode Penelitian Pendidikan Pendekatan Kuantitatif, Kualitatif dan R\&D. Bandung: Alfabeta.

Sukmasari, R. (2016). Efek Nikotin pada Otak hingga Bikin Orang Kecanduan Merokok.https://health.detik.com/read/ 2016/05/27/143137/3219420/76 3/efeknikotin-pada-otak-hingga-bikin-orangkecanduan-merokok (03 Mei 2017).

Sutha, D. W. (2016). Analisis lingkungan sosial terhadap perilaku merokok remaja di kecamatan pangarengan kabupaten Sampang Madura. Jurnal Manajemen Kesehatan STIKES Yayasan RS. Dr. Soetomo. 2 (1), April 2016:43-59

Wismanto, Y Bagusdan, Budi Sarwo. (2007). Stategi Penghentian Perilaku Merokok. Semarang: Unika Soegijapratana. http://eprints.unika.ac. id/236/1/Strahen_Prilaku_Mrokok.pdf (17 Januari 2017)

Yusnia, I. (2015). Meningkatkan Sikap Tidak Merokok Melalui Layanan Bimbingan Kelompok Dengan Model PBL. Penelitian Tindakan Bimbingan dan Konseling, 1, No. 2, (05 Mei 2015). 